\title{
Nagy István András': A büntetőeljárásról szóló 1998. évi XIX. törvény módosításáról szóló T/9553. számú törvényjavaslat a büntetőeljárás gyorsítására irányuló célkitüzés tükrében
}

Debreceni Jogi Műhely, 2009. évi (VI. évfolyam) 4. szám (2009. október) 15-22.

\section{Bevezetés}

Régóta megfogalmazott kritika a büntetőeljárásról szóló 1998. évi XIX. törvénnyel /a továbbiakban: Be./ szemben, hogy nem fektet kellö hangsúlyt arra, hogy az eljárást egyszerübbé, gyorsabbá, átláthatóbbá tegye. Ezek a követelmények egyrészt a büntetési célok hatékonyabb érvényesülését, másrészt a büntetőeljárásban részt vevő személyek / elsősorban a terhelt, illetve a sértett / érdekét, végül, de nem utolsó sorban a bizonyítás eredményességének előmozdítását hivatottak szolgálni.

A jelenleg hatályos Be. az eljárások típusát tekintve alapvetően két részre osztható: a klasszikusnak is nevezhető - nyomozási, vádemelési és bírósági szakot is magába foglaló, alapvetően a bírósági tárgyalásra épülő - ,,alapeljárásra”, illetőleg az ún. egyszerüsített, az ügyek differenciált elbírálására lehetőséget adó eljárásokra / magánvádas eljárás, bíróság elé állítás, eljárás a távollévő terhelttel szemben, lemondás a tárgyalásról, valamint a tárgyalás mellőzéses eljárás /. A törvényalkotói szándék szerint elsősorban ez utóbbi jogintézmények azok, amelyek a büntetőeljárás egyes garanciális elemeinek biztosítása mellett elősegítik az eljárás észszerü időn belüli, gyorsabb és egyszerübb lefolytatását.

Elsősorban e - egyszerünek semmiképp sem nevezhető - célkitüzést szem előtt tartva alkotta meg 2009 áprilisában a Magyar Köztársaság Kormánya a T/9553. számú törvényjavaslatát, amely mintegy 60 §-ban törekszik az eljárást gyorsabbá, egyszerübbé, átláthatóbbá tenni.

\section{A törvényjavaslat pontjai}

A koncepció alapvetően a fent említett ún. egyszerüsített eljárásokat / azon belül is legalaposabban, szinte minden arra vonatkozó szabályt érintve a tárgyalásról lemondásos eljárást / érinti - a büntetőeljárás gyorsítását szolgáló egyéb módosítások mellett. Emellett figyelmet fordít a jogalkalmazás során felmerült egyes hiányosságok megszüntetésére is.

Az ún. egyszerüsített eljárásokat érintő, az eljárás gyorsítását célzó módosítások:

\section{A.) A bíróság elé állitás / Be. XXIV. Fejezet /}

A törvényjavaslat 43. §-a a terhelt bíróság elé állítására rendelkezésre álló - a hatályos törvényben rögzített - 15 napos határidőt 30 napra emeli fel. A módosítást elsősorban az indokolja, hogy a viszonylag rövid, 15 napos határidő számos esetben kizárta a jogintézmény alkalmazásának lehetőségét, mivel nem bizonyult minden esetben elegendőnek a bizonyítékok beszerzésére. Azzal, hogy a határidőt kétszeresére emeli, a törvényjavaslat szélesebb körben teszi lehetővé a jogintézmény alkalmazását - ezzel nyilvánvalóan gyorsítva az adott eljárást.

\section{B.) Eljárás a távollévö terhelttel szemben / Be. XXV. Fejezet /}

A koncepció 46. §-a a vádlottal szemben elrendelt, az eljárás alkalmazásának feltételeként kikötött elfogatóparancs teljesítésére nyitva álló határidőt 60 napról 15 napra csökkenti. 
Amennyiben tehát az elfogatóparancs - immáron - 15 napon belül nem vezet eredményre, a bíróság tájékoztatja erről az ügyészt, akinek szintén 15 nap áll rendelkezésre a „távollétes eljárás" indítványozására. A jogintézménnyel kapcsolatos tapasztalatok azt mutatják, hogy a 60 napos kikötés / ún. várakozási idő / indokolatlanul hosszúnak bizonyult, az az eljárást jelentősen késlelteti, ezért mindenképpen indokolt a határidő 15 napra csökkentése. Ez a módosítás jelentősen meggyorsítja majd az eljárást.

\section{C.) Lemondás a tárgyalásról / Be. XXVI. fejezet /}

A törvényjavaslat 47 . §-a a Be. XXVI. fejezetében szabályozott tárgyalásról lemondásos eljárást alapjaiban változtatja meg. A legfontosabb változtatás, hogy az eljárás alapvető feltételéül az ügyész és a terhelt között a vádirat benyújtását megelözően kötött írásbeli megállapodás megkötését köti ki, melyben meg kell jelölni a terhelt által beismert büncselekmény leírását, Btk. szerinti minősítését, valamint az ügyész és a terhelt nyilatkozatát arra vonatkozóan, hogy milyen nemü és mértékü, illetve tartamú büntetést / annak alsó és felső határának megjelölésével /, illetve intézkedést vesz tudomásul.

Nagyon fontos változás, hogy az új szabályozás értelmében az ügyész - az általános szabályozástól eltérő módon - úgy tesz indítványt büntetés kiszabására, illetőleg intézkedés alkalmazására, hogy a vádiratban a joghátrány alsó és felső határát is megjelöli és a bíróság csak az ügyészi indítvány keretei között szabhat ki büntetést és alkalmazhat intézkedést. Felmerül a kérdés, hogy nem sérti-e ez a rendelkezés a Be. 1. és 2 . §-ában szabályozott bírói függetlenség alapelvét.

A koncepció miniszteri indokolása szerint nem, mivel a bíróságnak továbbra is lehetősége van arra, hogy amennyiben a vádiratban indítványozott joghátrány nemével, illetőleg az annak tartamára, mértékére tett ügyészi indítvánnyal nem ért egyet, az ügyet tárgyalásra utalja és a továbbiakban az általános szabályok szerint járjon el.

A javaslat - a jelenleg hatályos szabályozással egyező módon - nem teszi lehetővé valamenynyi büncselekmény esetén az eljárás alkalmazását. A legsúlyosabb / 8 évnél súlyosabb szabadságvesztéssel büntetendő / büncselekmények elkövetőivel szemben ugyanis - figyelemmel az ilyen cselekmények miatt lefolytatott eljárások összetettebb, bonyolultabb voltára, valamint a Btk. 83. § (1) bekezdésében megfogalmazott speciális prevenció elvére - továbbra sem indokolt a büntetőeljárás bírói szakaszának egyszerüsítése.

Ehhez képest új rendelkezés a jogintézmény vonatkozásában, hogy a javaslat a külön eljárást - általános szabályként - kizárja az olyan elkövetők esetében, akik a büncselekményt bünszervezetben követték el, illetve akiknek a büncselekménye halált okozott. Ezt a rendelkezést az indokolja, hogy ezeknek a jelentős tárgyi súlyú büncselekményeknek az elkövetőivel szemben nem indokolt ezen eljárási forma által nyújtott kedvezmények biztosítása / a külön eljárás lényege ugyanis továbbra is a terhelt anyagi jogi kedvezményben részesítése azáltal, hogy a tárgyaláshoz való jogáról lemondása esetén a Btk. 87/C. §-ban megjelölt csökkentett büntetési tételek az irányadók /.

Továbbra is fennmarad azonban az a rendelkezés, amelynek értelmében a 8 szabadságvesztésnél súlyosabban büntetendő büncselekmények esetén is lehetőség van a külön eljárás alkalmazásra az olyan terhelttel szemben, aki a büncselekményt bünszervezetben követte el, és a nyomozás során az ügy, illetőleg más büntető ügy bizonyításához hozzájárulva az ügyészszel, illetőleg a nyomozó hatósággal jelentős mértékben együttmüködött, de a nyomozás meg- 
szüntetésre bármely okból nem került sor / ez esetben a Btk. 98. §-ában és a Btk. Különös Részében a bünszervezetben elkövetett büncselekményre elöírt szigorúbb rendelkezések nem alkalmazhatók /.

A javaslat a külön eljárás bíróság felé történő kezdeményezésének jogát továbbra is az ügyész kezében hagyja amellett, hogy eltérő szabályokat állapít meg attól függően, hogy a nyomozás során beismerő vallomást tett terhelt a vádemelést megelözően kezdeményezte-e az ügyének a külön eljárás szerinti elbírálását vagy azt követően.

Ha a terhelt a nyomozás során bünösségére is kiterjedő beismerő vallomást tesz, az ügyész az utolsó nyomozási cselekmény / iratismertetés / foganatosítása után az ügy iratait megvizsgálja és a rendelkezésére álló harmincnapos határidőn belül dönt arról, hogy a nyomozás során beismerő vallomást tevő terheltnek az ügy nyilvános ülésen történő elbírálásra irányuló kezdeményezését elfogadja-e. Ha az ügyész a terhelti kezdeményezést elfogadja, akkor erről határozatot hoz, majd a határozat meghozatalát követö harminc napon belül vádat emel. A terhelti kezdeményezés elfogadása esetén a terhelt érdekeinek védelme céljából, a külön eljárás során ettől az időponttól kezdve védő részvétele kötelező.

Az ügyész a meghallgatás során közli a terhelttel az általa beismert büncselekmény leírását és Btk. szerinti minősítését, továbbá nyilatkozik arról, hogy milyen nemü, mértékü, tartamú büntetést, illetőleg intézkedést vesz tudomásul, azaz a büntetési célokat figyelembe véve milyen joghátrányt tart elfogadhatónak. Tájékoztatja - a hatályos szabályokhoz hasonlóan - ezen túlmenően a külön eljárás jogkövetkezményeiről, illetőleg arról is, hogy a megállapodás a bíróságra nézve nem bír kötelező jelleggel. A javaslat ugyanis rögzíti, hogy az ügyész és a terhelt közötti írásba foglalt megállapodás a tárgyalásról lemondás alapján folytatott eljárás célján túlmenően joghatás kiváltására nem alkalmas és amennyiben a bíróság hivatalból vagy az ügyész indítványára az ügyet tárgyalásra utalja, akkor a megállapodásban foglaltak sem az ügyészt, sem a terheltet nem kötik. E rendelkezést elsősorban az indokolja, hogy ha a megállapodás alapján az ügyet a bíróság döntése alapján mégsem nyilvános ülésen bírálják el, ezen iratokat ne lehessen sem az adott, sem más büntetőeljárásban felhasználni - ellenkező esetben a jogintézmény visszaélésekre is adhatna alapot.

Ha a terhelt az ügyész által ajánlott megállapodás tartalmi elemivel / különösen a joghátrány neme és mértéke tekintetében / egyetért, az ügyész és a terhelt között létrejön a külön eljárás alapját jelentő megállapodás.

A megállapodás megkötését követően az ügyész a megállapodásban foglalt azonos történeti tényállás, Btk. szerinti minősítés miatt emel vádat és az általános szabályoktól eltérően indítványt tesz az ügy nyilvános ülésen történő elbírálására, ennek keretében a konkrét tartamú büntetés kiszabására és intézkedés alkalmazására / azonban a joghátrány alsó és felső határát jelöli meg, nem pedig annak konkrét mértékét! /.

A javaslat lehetővé teszi a külön eljárás alkalmazást arra az esetre is, ha a nyomozás során a terhelt nem tett beismerő vallomást, azonban a vádirat kézbesítést követő 15 napon belül, az ügyésznél kezdeményezi ügyének nyilvános ülésen való elbírálását. A bünösségre is kiterjedő beismerő vallomás hiányából adódóan a javaslat annyiban tér el a korábbi ügyész eljárására megállapított rendelkezésektől, hogy az ügyész a meghallgatás során a vád tárgyává tett cselekmény leírását közli. Egyebekben az ügyész eljárására értelemszerüen a korábbi szakasznál írt rendelkezések az irányadók. Utalni kell arra, hogy a meghallgatás során, ha a vádlott beismerő vallomást tesz, az ügyésznek a vád tárgyává tett cselekményröl részletesen ki kell hall- 
gatnia, mivel ennek ismeretében tud dönteni arról, hogy a tárgyalásról lemondás alapján folytatott eljárás feltételei fennállnak-e.

A módosító javaslat a bíróság eljárást is érinti. A külön eljárás alapgondolata, hogy a tárgyalásról lemondás alapján meghozott ítélet az ügyész, a terhelt és a bíróság által is elfogadhatónak tartott konszenzusán alapul, a bíróság csak e konszenzus keretein belül dönthet. Ha azonban a bíróság a megállapodás valamelyik elemével nem ért egyet, akkor az ügyet az általános szabályok szerint tárgyalásra utalja / amennyiben a benyújtott iratok alapján kételye merül a vádlott bünösségét, vagy a cselekmény minősítését illetően, a bíróság ki sem tüzi az ügyet nyilvános ülésre /. Fontos garanciális szabály, hogy - eltérő rendelkezés hiányában - a bíróság valamennyi, a tárgyalás előkésztése / Be. XII. fejezet / során elvégezhető intézkedéseket megteheti a nyilvános ülés eredményes megtartása érdekében.

A nyilvános ülésen az ügyész a vádat és indítványait ismerteti, majd a bíróság a vádlottat tájékoztatja a tárgyalásról lemondás alapján folytatott eljárás következményeiről / különösen arról, hogy a bünösségét a beismerő vallomásra alapítja, további bizonyítási eljárást nem vesz fel és a bünösség megállapítása, a váddal egyező tényállás, minősítés, a vádirattal azonos büntetés, illetőleg intézkedés neme, mértéke, tartama miatt fellebbezéssel nem élhet /. A bíróság tájékoztatását követően a vádlottnak lehetősége van a védőjével való tanácskozásra és ezt követően nyilatkozik arról, hogy bünösségét elismeri-e és a tárgyaláshoz való jogáról lemonde.

A vádlott beleegyező nyilatkozatát követően a bíróság ismételten megvizsgálja, hogy az ügyet nyilvános ülés keretében bírálja-e el vagy az ügyet tárgyalásra utalja. Ennek eldöntése érdekében az ügyészhez vagy a vádlotthoz vagy a védőhöz kérdéseket intézhet. Ezt követően, ha a nyilvános ülés megtartásnak nincs akadálya, a bíróság a vádlottat a vád tárgyát képező cselekményröl kihallgatja.

A koncepció rendelkezik arról az esetről is, ha vádlott a bünösségét elismerte ugyan és a tárgyaláshoz való jogáról is lemondott, azonban a bíróság előtt a vallomástételt megtagadja. Ebben az esetben a bíróság az ügyet tárgyalásra utalja. Ennek nyilvánvaló indoka az, hogy a bíróság a vádlott bünösségét nem tudja a bünösségére is kiterjedő beismerő vallomására alapítani és egyéb bizonyítást a nyilvános ülésen - a külön eljárás szabályai miatt - nem vehet fel.

A bíróság az ügyet tárgyalásra utalja abban az esetben is, ha a vádlott kihallgatását követően olyan körülmények merülnek fel, amelyek kétségessé teszik a vádlott beszámítási képességét, beismerő vallomásának önkéntességét vagy hitelt érdemlőségét, illetőleg ha a bíróság előtti nyilatkozata a nyomozás során tett beismerő vallomásától lényegesen eltér. Ha a bíróság a vádlott kihallgatását követően is elegendőnek tartja, hogy a terhelt büntetőjogi felelősségéről nyilvános ülésen döntsön, a vádlottat a büntetéskiszabási körülményekre is kihallgatja.

A tárgyalásról lemondás alapját jelentő megállapodás az ügyész és a terhelt konszenzusán alapszik, ami kiterjed a terhelt által beismert büncselekmény tényállására, Btk. szerinti minősítésére, a kiszabandó büntetés, intézkedés nemére, illetőleg tartamának, mértékének alsó- és felső határára.

A külön eljárás alapgondolatából következik, hogy a fellebbezési jog korlátozott: csak a megállapodással nem érintett járulékos kérdésekre, / pl.: a lefoglalásra, a polgári jogi igényre, a szülői felügyeleti jog megszüntetésre, a bünügyi költség viselésére, az előzetes fogvatartás beszámítására / irányulhat. 
A másodfokú bírósági eljárásban a revízió elve - az általános szabályokhoz képest - szűkebb körben érvényesül, mivel a másodfokú bíróság a váddal egyező tényállás, minősítés esetén az első fokú ítéletet csak akkor változtathatja meg, ha a terhelt felmentésének vagy az eljárás megszüntetésnek van helye. Ezek az esetek nyilvánvalóan akkor következhetnek be, ha ez az iratok alapján egyértelmủen megállapítható / pl.: a vádlott halála esetén /.

Új szabályként kívánja bevezetni a javaslat, hogy amennyiben az elsőfokú bíróság a külön eljárás feltételeinek hiánya ellenére jár el, a másodfokú bíróság az elsőfokú bíróság ítéletét hatályon kívül helyezi, és az elsőfokú bíróságot új eljárásra utasítja. Az új eljárás során a bíróság előtti eljárást az általános szabályok szerint kell lefolytatni.

Érdemes megjegyezni, hogy annak ellenére, hogy a jogintézmény jelentős eljárást gyorsító hatással bír, mégsem vált a gyakorlatban gyakran alkalmazott eljárássá / 2004-ben a helyi bíróságokon országos szinten 187, a megyei bíróságokon 4; 2005-ben 182, illetve 5; 2006-ban 202, illetve 8; 2007-ben 194, illetve 12, míg 2008-ban 192, illetve 13 esetben alkalmazták /.

Ennek oka elsősorban abban áll, hogy a törvény értelmében a külön eljárást a terheltnek kell kezdeményeznie. A jogintézmény alkalmazási feltételeiből következik, hogy arra elsősorban a viszonylag kisebb súlyú büncselekmények esetén van lehetőség. Ezekben az esetekben a védő részvétele nem feltétlenül kötelező, így - bár a törvény az ügyésznek ezzel kapcsolatban tájékoztatási kötelezettséget ír elő - az esetek túlnyomó többségében a terheltnek önállóan kell döntenie arról, hogy tesz-e beismerő vallomást és kezdeményezi-e ügyének nyilvános ülésen való elbírálását.

A módosítás ebben az irányban nem tartalmaz változást, a külön eljárás kezdeményesének jogát továbbra is a terhelt kezében hagyja, így kérdéses, hogy a jogintézmény a jövőben beváltja-e a hozzá füzött reményeket.

\section{D.) A tárgyalás mellözése / Be. XXVII. Fejezet /}

A javaslat 48. §-a két pontot érintően módosítja a „tárgyalás mellőzéses eljárás” szabályait. Egyrészt lehetővé teszi / és ezzel egyúttal szélesíti is a jogintézmény alkalmazási körét / a bíróság számára, hogy a jövőben - a többi feltétel fennállása mellett - ügyészi indítvány hiányában is tárgyalás mellőzésével hozzon határozatot; másrészt megnyitja a közérdekü munka, mint föbüntetés alkalmazásának a lehetőségét.

Az ügyészi indítványnak a jogintézmény alkalmazásának feltételei közül való mellőzése felveti a garanciális jogok sérelmének lehetőségét, azonban a Be. 548. § (1) bekezdésében rögzített szabály / nevezetesen hogy az ügyész a tárgyalás mellőzéses eljárás keretében hozott határozat kézhezvételét követő 8 napon belül tárgyalás tartását kérheti / érintetlenül hagyása áthidalja ezt a kételyt.

A közérdekü munkának, mint föbüntetésnek az eljárás során alkalmazható szankciók közé való beillesztését egyértelmüen a büntetőjogi szankciók alkalmazásához kapcsolódó fokozatosság elvéből eredő igény indokolja. 
A Be. gyorsítását szolgáló egyéb módosítások:

\section{E.) A bíró kizárása / Be. II. fejezet /}

A koncepció 2. §-a a gyakorlatban az egyik leggyakrabban alkalmazott eljárást késleltető, elhúzó taktikai elemként használt szabályozást módosítja azzal, hogy az eljáró bírónak lehetőséget ad - az eljárás folytatása mellett - az ügydöntő határozat meghozatalára is abban az esetben, ha a vele szemben felhozott kizárási okot a 21. § (1) bekezdés e.) pontjára / elfogultság / alapították. Ezzel tulajdonképpen akadályát képezi annak a - tapasztalatok szerint fennálló - tendenciának, mely szerint az ügyfelek az eljárást rendszeresen azzal törekednek késleltetni, hogy túlnyomó többségben alaptalan elfogultsági indítványt terjesztenek elő az ügyben eljáró bíróval szemben / akár az ügydöntő határozat meghozatala céljából való visszavonulás előtt is / - késleltetve ezzel az eljárást és az ügydöntő határozat meghozatalát egyaránt.

A javaslat e szabályozása egyszersmind véglegesen különbséget tesz az ún. abszolút / Be. 21. $\S(1)$ bekezdés a.) - d.) pontja / és relatív kizárási okok között is. A módosítás egy új bekezdéssel / 2. § (5) bekezdés / lényegesen megrövidíti az eljárást azzal, hogy lehetővé teszi a bíróság számára, hogy az ugyanazon bíró ellen, ugyanazon pontra alapított, alaptalan kizárás iránti bejelentést indokolás nélkül elutasítsa.

\section{F.) Az idézés és az értesités / Be. VI. fejezet /}

A módosító javaslat 10. §-a az idézés és értesítés körében kiegészíti a hatályos szabályozást a 67/A. §-szal, melynek értelmében a jövőben a bíróság, az ügyészség, a nyomozó hatóság és a védő, valamint a jogi képviselő vagy a képviselőként eljáró ügyvéd egymással az írásbeli kapcsolatot a külön jogszabályok szerint meghatározott központi rendszer útján tartja.

E módosítást a miniszteri indokolás szerint a hatósági eljárások gyorsítását fő célként kitüző, az Országgyülés napirendjén lévő elektronikus közszolgáltatásról szóló törvényjavaslat várható bevezetése indokolja, amely egy ún. központi rendszert kíván létrehozni a hatóságok és a felsorolt, büntetőeljárásban részt vevő személyek közötti kommunikáció felgyorsítása céljából. A módosítás hatálybalépését követően tehát a bíróság, az ügyészség és a nyomozó hatóság az eljárásuk során keletkezett valamennyi iratot / így különösen a másik szervhez intézett megkeresést, előterjesztést, indítványt / a felállítandó központi rendszeren keresztül küldené meg, illetőleg a védő, jogi képviselő és a képviselőként eljáró ügyvéd a fenti hatóságok felé szintén az ügyfélkapun keresztül továbbítaná valamennyi beadványát.

A 37. $\S$ ehhez kapcsolódóan a fellebbezés körében is lehetővé teszi annak elektronikus úton, számítógépen keresztül történő benyújtását.

E ponton szükséges megjegyezni, hogy nem tünik túl reális célkitüzésnek az iratok elektronikus kézbesítésének a közeljövőben való bevezetése, hiszen a bíróságok többségén csak nemrégiben sikerült elérni, hogy minden bíró saját számítógéphez jusson, továbbá az egyes bíróságokon az irattári anyag állagának megóvása is gondot jelent - nem is beszélve a bíróságoknak otthont adó épületek legtöbbjének állapotáról. Ezzel egybecseng az Országos Igazságszolgáltatási Tanács Hivatalának / OITH / álláspontja is, mely szerint a rendszer bevezetéséhez a pénzügyi-technikai feltételek nem biztosítottak és nem készült hatástanulmány sem arra vonatkozóan, hogy az elektronikus ügyvitelhez milyen informatikai és egyéb beruházás, továbbképzés, oktatás lenne szükséges a bíróságokon és az ügyészségeken. 
A koncepció új jogintézményként tervezi bevezetni a tárgyalási őrizetet, amely a vádlott megjelenési kötelezettségét hivatott elősegíteni azzal, hogy amennyiben szabályszerü idézés ellenére nem jelenik meg a tárgyaláson és elővezetése nem járt sikerrel, az eljáró bíróságnak lehetősége nyílik tárgyalási őrizetbe venni.

Az új jogintézménynek egyértelmüen eljárást gyorsító hatása lenne, hiszen a vádlottnak a tárgyalásokról való, szabályszerü idézés ellenére történő távolmaradása számos esetben idézte és idézi elő a büntetőeljárások tartamának elhúzódását.

A törvényjavaslat 17 . $\S$-a ennek megfelelően beilleszti az új kényszerintézkedést az őrizetbe vételről rendelkező Be. 126. (2) bekezdésébe - hiszen értelemszerüen erre is az őrizet szabályai az irányadók.

A 35. §-ban megfogalmazott módosító javaslat ugyanakkor a tárgyalás megnyitása / Be. XIII. fejezet / körében teszi lehetővé a bíróság számára a tárgyalási ơrizet alkalmazását abban az esetben, ha a bírósági eljárás során a meg nem jelent vádlott elővezetésének elrendelésére már sor került. Ebben az esetben ugyanis az elfogatóparancs kibocsátása mellett - amennyiben a vádlott lakóhelye, illetve tartózkodási helye ismert - a bíróságnak lehetősége nyílik a vádlottal szemben tárgyalási őrizet elrendelésére is.

A tárgyalási őrizet foganatba vételét követően a vádlottat a kényszerintézkedést elrendelő bíróság elé kell állítani. A bíróság ilyen esetekben a vádlottat meghallgatja, és ennek függvényében rendelkezik a vádlott szabadon bocsátásáról vagy - amennyiben az eljárási cselekményeken való jelenléte másképp nem biztosítható - súlyosabb kényszerintézkedés alkalmazásáról.

Ez a módosítás egyszersmind megoldja azt a problémát, amellyel a bíróságok elég gyakran szembesültek. Olyan esetekben ugyanis, amikor - bár lakcíme ismert, de - a vádlott annak ellenére sem jelenik meg a bírósági tárgyalásokon, hogy vele szemben elfogatóparancs kibocsátására került sor, a bíróságok akként tudtak tovább haladni az ügyben, hogy tanácsülésen tehát nem kontradiktórius eljárás keretében - a vádlott előzetes letartóztatásáról rendelkeztek. Ez a megoldás - vádlott személyes meghallgatása hiányában - nyilvánvalóan nem volt túl elegáns, ám az újonnan bevezetett kényszerintézkedés megoldást jelent e gyakran előforduló problémára.

\section{H.) A tárgyalás folytonossága / Be. XIII. fejezet /}

A büntetőeljárás gyorsítására és ésszerü időn belül történő befejezésére irányuló törvényalkotói célkitüzés megvalósítása szempontjából rendkívüli jelentőséggel bír a koncepció 36 . §-a, mely a Be. 287 . § (4) bekezdését módosítja. Ez lehetővé teszi, hogy a tárgyalás folytatására a tárgyalás anyagának ismertetésével akkor is sor kerülhessen, ha a bíróság tagjai közül - az ülnökök mellett - a hivatásos bíró személyében következik be változás. A hatályos törvényszöveg ugyanis ezt a lehetőséget kizárja.

A módosítás a folytonosság követelményét továbbra is fenntartja azzal, hogy a hivatásos bíró belátására bízza, hogy kívánja-e a korábban kihallgatott tanúk ismételt idézését és meghallgatását; emellett továbbra is marad lehetősége az ügyésznek, a vádlottnak és a védőnek arra, 
hogy a tárgyalás anyagának ismertetését követően arra észrevételt tegyenek, illetve annak kiegészítését kérjék.

\section{I.) A polgári jogi igény elbírálása / Be. XIII. fejezet /}

A törvényjavaslat 38. §-a kötelezővé teszi a bíróságok számára, hogy azokban az esetekben, amikor a polgári jogi igény kérdésében való érdemi döntés nem okozhat különösebb nehézséget / a büncselekménnyel okozott kár, vagyoni hátrány, adóbevétel-csökkenés, vámbevételcsökkenés összegszerüsége, illetve a büncselekmény elkövetési értéke megállapítható és a bíróság meg is állapítja /, a bíróság - a megállapított összeg erejéig - bírálja el a magánfél által előterjesztett polgári jogi igényt.

A gyakorlatban ugyanis gyakran fordult és fordul elő, hogy a büntető ügyekben eljáró bíróságok ezekben az „egyszerü megítélésü ügyekben” is éltek a Be. 335. § (1) bekezdés második mondatában lefektetett lehetöséggel és a polgári jogi igény érvényesítését egyéb törvényes útra utasították, amely intézkedésükkel - legalábbis e tekintetben - jelentősen hozzájárultak az eljárás elhúzódásához.

\footnotetext{
${ }^{1}$ Bírósági titkár, Debreceni Ítélőtábla
} 